\title{
High Receptor Binding Affinity of Lipoproteins in Atypical Dysbetalipoproteinemia (Type III Hyperlipoproteinemia)
}

\author{
David A. Chappell \\ Gladstone Foundation Laboratories for Cardiovascular Disease, Cardiovascular Research Institute, Department of Internal Medicine, \\ University of California, San Francisco, California 94140; and Department of Internal Medicine, \\ University of Iowa College of Medicine, Iowa City, Iowa 52242
}

\begin{abstract}
Familial dysbetalipoproteinemia (or type III hyperlipoproteinemia) is characterized by the presence of abnormal, cholesteryl ester-rich $\beta$-very low density lipoproteins ( $\beta$-VLDL) in the plasma. Subjects with typical dysbetalipoproteinemia are homozygous for an amino acid substitution in apolipoprotein (apo-) $E$ at residue 158 and have defective apo-E-mediated binding of both pre- $\beta-V L D L$ and $\beta-V L D L$ to apo-B,E(LDL) (or LDL) receptors (1988. Chappell, D. A., J. Clin. Invest. 82:628-639). To understand the effect of substitutions in apo-E at sites other than residue 158 , nine dysbetalipoproteinemic (dys- $\beta$ ) subjects who were either homozygous or heterozygous for substitutions in apo-E at atypical sites were studied. These substitutions occurred at residue $142(n=6), 145$ ( $n$ $=2)$, or $146(n=1)$ and are known to cause less defective binding than does the 158 substitution. The chemical composition and electrophoretic mobility of pre- $\beta-V L D L$ and $\beta-V L D L$ from atypical and typical dys- $\beta$ subjects were indistinguishable. However, lipoproteins from atypical and typical dys- $\beta$ subjects differed in their affinity for the apo-B,E(LDL) receptor on cultured human fibroblasts. The pre- $\beta$-VLDL and $\beta$ VLDL from atypical dys- $\beta$ subjects had 640 - or 17 -fold higher affinity, respectively, than did corresponding lipoproteins from typical dys $-\beta$ subjects. The higher binding affinity of lipoproteins from atypical dys $-\beta$ subjects was associated with a higher ratio of apo-E to total apo-C. Since higher binding affinity should cause more rapid receptor-mediated clearance of $\boldsymbol{\beta}$ VLDL in atypical than in typical dys- $\beta$ subjects in vivo, the mechanism of $\beta$-VLDL accumulation may differ in these two groups.
\end{abstract}

\section{Introduction}

Familial dysbetalipoproteinemia (or type III hyperlipoproteinemia) is characterized by the presence of abnormal, cholesteryl ester-rich $\beta$-migrating very low density lipoproteins ( $\beta$ VLDL) in the plasma (1). Apolipoprotein (apo-) E was first implicated in the pathogenesis of dysbetalipoproteinemia when Havel and Kane reported the abundance of apo-E in

Address reprint requests to Dr. Chappell, Department of Internal Medicine, University of Iowa College of Medicine, Iowa City, IA 52242.

Received for publication 13 March 1989 and in revised form 8 August 1989.

J. Clin. Invest.

(c) The American Society for Clinical Investigation, Inc.

$0021-9738 / 89 / 12 / 1906 / 10 \$ 2.00$

Volume 84, December 1989, 1906-1915
$\beta$-VLDL isolated from dysbetalipoproteinemic (dys- $\beta$ ) ${ }^{1}$ subjects (2). Later, by isoelectric focusing, Utermann et al. showed that apo-E from dys- $\beta$ subjects was abnormal (3). There are three common isoforms of apo-E, (E2, E3, and E4), which differ in isoelectric focusing positions as a result of substitutions involving charged amino acids $(4,5)$. Apolipoprotein E4 differs from normal apo-E3 by the substitution of arginine for cysteine at residue $112\left(\mathrm{Cys}_{112} \rightarrow \mathrm{Arg}\right)$, whereas apo-E2 differs from apo-E3 by the substitution of cysteine for arginine at residue $158\left(\mathrm{Arg}_{158} \rightarrow \mathrm{Cys}\right)(5,6)$. Most dys- $\beta$ subjects are homozygous for the substitution at residue 158 ( $\mathrm{Arg}_{158} \rightarrow \mathrm{Cys}$ ) and have an E2/2 phenotype $(6,7)$. These subjects are said to have typical dysbetalipoproteinemia, which is inherited as an autosomal recessive trait. Heterozygous individuals with the E3/2 phenotype rarely develop dysbetalipoproteinemia. However, dys- $\beta$ subjects with E3/3, E3/2, or E2/1 phenotypes have been described (8-12). In addition, a variety of amino acid substitutions may cause the same phenotype.

Apolipoprotein E binds to apo-B,E(LDL) (or LDL) receptors with high affinity. All of the known substitutions in apo-E that are associated with dysbetalipoproteinemia disrupt this binding to some extent (for review, see reference 1). Schneider et al. showed that apo-E isolated from dys- $\beta$ subjects may have either very defective or nearly normal receptor binding compared to the binding of apo-E from normal individuals (13). Normal apo-E3, purified and reconstituted into phospholipid complexes, has 50-, 5-, 2.5-, or 2-fold higher affinity than does apo-E with a substitution at residue $158,142,146$, or 145 , respectively $(1,5,8)$.

The severity of the binding defect caused by the various substitutions in apo-E does not correlate with the severity of dysbetalipoproteinemia $(6,13)$. The vast majority of individuals homozygous for the most defective form of apo-E do not develop clinically significant hyperlipidemia. These individuals have $\beta$-VLDL in their plasma but have normal or even low cholesterol concentrations $(6,14-16)$. Clearly, factors other than defective binding of apo-E to apo-B,E(LDL) receptors are important in the expression of this disease. These factors include obesity, the inheritance of hypertriglyceridemia or familial combined hyperlipidemia, and the effects of estrogen or thyroid hormones (17-23).

The mechanism of $\beta$-VLDL formation is partially understood. Pre- $\beta$-VLDL appear to be precursors of $\beta$-VLDL. Pre- $\beta$-VLDL are larger, more triglyceride-rich particles with higher flotation rates than $\beta$-VLDL and may be converted to

1. Abbreviations used in this paper: dys- $\beta$, familial dysbetalipoproteinemic; $\mathrm{EC}_{50}$, the $50 \%$ effective concentration of competition for ${ }^{125} \mathbf{I}-$ LDL binding to receptors; pre- $\beta$-VLDL, pre- $\beta$-migrating very low density lipoproteins. 
$\beta$-VLDL during lipolysis (24-28). Accelerated lipolysis induced by intravenous heparin causes the formation of $\beta$ VLDL and a decrease in pre- $\beta$-VLDL in subjects with either normal or abnormal apo-E (25-28). Recently, I showed that pre- $\beta$-VLDL from typical dys- $\beta$ subjects had extremely low affinity for apo-B,E(LDL) receptors (27). In these subjects, defective binding of pre- $\beta$-VLDL to receptors could result in delayed receptor-mediated clearance and increased conversion to $\beta$-VLDL during lipolysis. Their $\beta$-VLDL had 68 -fold higher binding affinity than their pre- $\beta$-VLDL (27). However, the binding of $\beta$-VLDL from the typical dys- $\beta$ subjects was defective when compared with heparin-induced $\beta$-VLDL from subjects homozygous for normal apo-E3 (27). These data suggest that defective binding of both pre- $\beta$-VLDL and $\beta$-VLDL to receptors may be involved in the formation and accumulation of $\beta$-VLDL in typical dys- $\beta$ subjects.

In this study, dys- $\beta$ subjects who were either heterozygous or homozygous for amino acid substitutions in apo-E at atypical sites (residue 142, 145, or 146) are defined as having atypical dysbetalipoproteinemia. To understand the role of atypical apo-E mutations in the pathogenesis of dysbetalipoproteinemia, the chemical composition, apolipoprotein content, and receptor binding affinities of their $d<1.006 \mathrm{~g} / \mathrm{ml}$ lipoproteins were determined. In addition, cholesterol-fed rabbits and cholesterol-fed dogs, animal models in which there is $\beta$-VLDL accumulation (29-31), were studied to see whether their $d$ $<1.006 \mathrm{~g} / \mathrm{ml}$ lipoproteins resembled those from typical or those from atypical dys- $\beta$ subjects.

\section{Methods}

\section{Human subjects}

The subjects studied are described in Table I. 10 subjects were members of a single family (family A.) in which dysbetalipoproteinemia was inherited as an autosomal dominant trait through four generations $(9,10)$. All family members had an E3/3 phenotype. However, family members with dysbetalipoproteinemia were heterozygous for normal apo-E3 and a double mutation in apo-E, that resulted in no net change in the charge $\left(\operatorname{Arg}_{142} \rightarrow \mathrm{Cys}, \mathrm{Cys}_{112} \rightarrow \mathrm{Arg}\right)(10)$. Family members who did not have dysbetalipoproteinemia had a double pre- $\beta$ pattern on agarose electrophoretograms of their VLDL (9). Subject 3 was taking gemfibrozil ( $600 \mathrm{mg}$ twice daily) at the time of this study. The other dys- $\beta$ subjects were not taking medication. Subjects 11 and 12 had an E2/2 phenotype and were homozygous for the $\operatorname{Arg}_{145} \rightarrow$ Cys substitution in apo-E $(5,32)$. Subject 13 had an E3/2 phenotype and had had a dys- $\beta$ profile (8); however, at the time of this study he had a type $\mathrm{V}$ lipoprotein phenotype as determined by agarose electrophoresis and analytical ultracentrifugation (data not shown). All subjects gave written informed consent for the study; the study was approved by the Human Research Committee at University of California, San Francisco.

\section{Lipoprotein preparation}

Subjects fasted for $14 \mathrm{~h}$ before blood sampling. Blood samples were adjusted to contain $1 \mathrm{mg}$ EDTA (sodium salt)/ml and were immediately placed on ice. The plasma was separated from the cells by centrifugation at $2,000 \mathrm{rpm}$ for $15 \mathrm{~min}$ at $4{ }^{\circ} \mathrm{C}$. To prevent proteolytic degradation, the plasma was adjusted to contain $10,000 \mathrm{U}$ of aprotinin/liter (Mobray Chemical Corp., New York), $1 \mathrm{mM}$ benzamidine, $1 \mathrm{mM}$ PMSF, and $80 \mathrm{mg}$ of gentamicin/liter (Sigma Chemical Co.. St. Louis. MO) (33).

Isolation of lipoproteins by ultracentrifugation. The $d<1.006 \mathrm{~g} / \mathrm{ml}$ lipoproteins and LDL were isolated from the plasma by ultracentrifugation (34). The $S_{f}>100, S_{f} 60-100$, and $S_{f} 20-60$ flotation fractions were isolated according to the method of Lossow et al. (35).
Pevikon block electrophoresis. Pre- $\beta$-VLDL and $\beta$-VLDL were isolated by Pevikon block electrophoresis of the total $d<1.006 \mathrm{~g} / \mathrm{ml}$ lipoproteins (Mercer Consolidated Corp., Yonkers, NY) $(36,37)$. Human LDL were used as a reference for $\beta$-electrophoretic mobility to aid in determining the fractionation of pre- $\beta$-migrating and $\beta$-migrating lipoproteins on each Pevikon block (27).

Lipoprotein and apolipoprotein characterization. Measurement of protein, cholesterol, triglyceride, phospholipid, and cholesteryl ester concentrations was done in duplicate or triplicate and using different aliquot sizes. Protein concentration was determined by the method of Lowry et al. (38); bovine albumin was used as the standard. Cholesterol and triglyceride concentrations were measured by using a colorimetric enzymatic assay (Boehringer-Mannheim Corp., Indianapolis, IN). Phospholipid concentration was estimated from the phosphorus content (39). Cholesteryl ester concentration was estimated by using gasliquid chromatography (27). The relative apolipoprotein content of lipoproteins was determined using electrophoresis on 5-20\% SDSpolyacrylamide gradient gels stained with Coomassie blue R-250 (27, 40). Coomassie blue-stained gels were scanned at $600 \mathrm{~nm}$ on a CS-930 scanner (Shimadzu, Kyoto, Japan). Silver staining was performed on some gels (41). The apo-E phenotypes were determined as described (42). The molecular weights of lipoproteins were estimated from their average molecular volume assessed by electron microscopy (43) and by the partial specific volumes of the chemical constituents $(27,44)$. The electrophoretic mobility of each fraction was determined by $1 \%$ agarose electrophoresis (Corning, Palo Alto, CA) (27).

\section{Fibroblast binding assays}

Normal human fibroblasts were grown in $35-\mathrm{mm}$ petri dishes (45). Lipoproteins were iodinated (sp act $200-500 \mathrm{cpm} / \mathrm{ng}$ ) by the iodomonochloride method (46). The ability of $d<1.006 \mathrm{~g} / \mathrm{ml}$ fractions at various concentrations to compete for the binding of ${ }^{125} \mathrm{I}-\mathrm{LDL}$ at $2 \mu \mathrm{g}$ of protein $/ \mathrm{ml}$ at $4^{\circ} \mathrm{C}$ was determined in duplicate (45). Binding data were analyzed by nonlinear least-squares curve fitting (allfit) $(27$, $47,48)$.

Monoclonal antibodies that specifically inhibit binding by apo-E (1D7) or apo-B100 (4G3) to the apo-B,E(LDL) receptor were generously provided by Dr. Y. Marcel and Dr. R. Milne, Clinical Research Institute of Montreal $(49,50)$. The monoclonal antibody MB47, which specifically inhibits the binding of apo-B100, was generously provided by Dr. S. Young, of the Gladstone Foundation Laboratories (51). The ability of 1D7, 4G3, or MB47 to inhibit the binding of ${ }^{125} \mathrm{I}-\mathrm{VLDL}$ fractions to cultured human fibroblasts at $4{ }^{\circ} \mathrm{C}$ was determined by incubating medium containing 5-20 $\mu \mathrm{g}$ of antibody $/ \mathrm{ml}$ and $1 \mu \mathrm{g}$ of ${ }^{125} \mathrm{I}-\mathrm{VLDL} / \mathrm{ml}$ for $1 \mathrm{~h}$ at $25^{\circ} \mathrm{C}$ before use in the binding assays $(27,52)$. Nonspecific binding was defined as the amount bound in the presence of 100 -fold excess of the corresponding unlabeled lipoprotein fraction. All measurements were performed in duplicate.

Animal studies. Rabbits and foxhounds were fed a high-cholesterol. high-saturated-fat diet (31). The plasma cholesterol concentration in these animals was $>1,000 \mathrm{mg} / \mathrm{dl}$. Pre- $\beta$-VLDL and $\beta$-VLDL were isolated by using the same method described above for human lipoproteins.

\section{Results}

The dys- $\beta$ subjects studied were $0-45 \%$ above their ideal body weight (Table I). Members of family A. who did not have dysbetalipoproteinemia had a double pre- $\beta$ pattern; furthermore, three were hypercholesterolemic. The plasma cholesterol and triglyceride concentrations in the dys- $\beta$ subjects ranged from minimally to markedly elevated.

Characterization of $d<1.006-\mathrm{g} / \mathrm{ml}$ lipoproteins. Lipoproteins were isolated by Pevikon block electrophoresis of the total $d<1.006-\mathrm{g} / \mathrm{ml}$ fraction and by sequential ultracentrifugal flotation of whole plasma. The relative content of pre- $\beta$ $\mathrm{VLDL}$ and $\beta-\mathrm{VLDL}$ in the $d<1.006-\mathrm{g} / \mathrm{ml}$ fractions as as- 
Table I. Characteristics of Subjects Studied

\begin{tabular}{|c|c|c|c|c|c|c|c|c|}
\hline Subject* & Age & Sex & $\%$ IBW $^{\ddagger}$ & $\mathrm{C}^{\S}$ & $\mathrm{TG}^{8}$ & Lipoprotein phenotype" & $\begin{array}{c}\text { Apo-E } \\
\text { phenotype }\end{array}$ & Apo-E genotype' \\
\hline & $y r$ & & & & & & & \\
\hline \multicolumn{9}{|c|}{ Family A } \\
\hline 1 & 72 & $\mathrm{~F}$ & 110 & 259 & 222 & Dys- $\beta$ (type III) & $E 3 / 3$ & N/Arg $142 \rightarrow$ Cys, Cys $_{112} \rightarrow$ Arg \\
\hline 2 & 51 & $\mathbf{F}$ & 124 & 298 & 129 & Dys- $\beta$ (type III) & E3/3 & N/Arg $142 \rightarrow$ Cys, Cys $_{112} \rightarrow$ Arg \\
\hline 3 & 26 & $\mathbf{M}$ & 116 & 697 & 852 & Dys- $\beta$ (type III) & E3/3 & N/Arg $142 \rightarrow$ Cys, Cys $_{112} \rightarrow$ Arg \\
\hline 4 & 23 & $\mathbf{F}$ & 145 & 285 & 264 & Dys- $\beta$ (type III) & E3/3 & N/Arg ${ }_{142} \rightarrow$ Cys, Cys $_{112} \rightarrow$ Arg \\
\hline 5 & 22 & $\mathbf{F}$ & 110 & 525 & 316 & Dys- $\beta$ (type III) & E3/3 & N/Arg $142 \rightarrow$ Cys, Cys $_{112} \rightarrow$ Arg \\
\hline 6 & 6 & $\mathbf{M}$ & 100 & 414 & 233 & Dys- $\beta$ (type III) & $\mathrm{E} 3 / 3$ & N/Arg ${ }_{142} \rightarrow$ Cys, Cys $_{112} \rightarrow$ Arg \\
\hline 7 & 51 & $\mathbf{M}$ & 136 & 216 & 119 & Double pre- $\beta$ & $\mathrm{E} 3 / 3$ & $\mathrm{~N} / \mathrm{N}$ \\
\hline 8 & 27 & $\mathbf{F}$ & 133 & 284 & 90 & Double pre- $\beta$ & E3/3 & $\mathrm{N} / \mathrm{N}$ \\
\hline 9 & 18 & $\mathbf{M}$ & 118 & 361 & 118 & Double pre- $\beta$ & E3/3 & $\mathrm{N} / \mathrm{N}$ \\
\hline 10 & 7 & $\mathbf{F}$ & 119 & 290 & 67 & Double pre- $\beta$ & E3/3 & $\mathrm{N} / \mathrm{N}$ \\
\hline \multicolumn{9}{|c|}{ Other dys- $\beta$ subjects } \\
\hline 11 & 58 & $\mathbf{M}$ & 110 & 224 & 223 & Dys- $\beta$ (type III) & $\mathrm{E} 2 / 2$ & $\operatorname{Arg}_{145} \rightarrow$ Cys/Arg $145 \rightarrow$ Cys \\
\hline 12 & 44 & $\mathbf{M}$ & 122 & 235 & 169 & Dys- $\beta$ (type III) & $\mathrm{E} 2 / 2$ & $\operatorname{Arg}_{145} \rightarrow$ Cys/Arg $145 \rightarrow$ Cys \\
\hline 13 & 56 & $\mathbf{M}$ & 112 & 474 & 1480 & Type V & E3/2 & N/Lys ${ }_{146} \rightarrow$ Gln \\
\hline
\end{tabular}

* Subjects 1-5, 7-9, and 11-13 have been described previously (see references 5, 8-10, and 32). $\%$ IBW, percent of ideal body weight from New York Metropolitan Life tables. ${ }^{\S} \mathrm{C}$ and TG, plasma cholesterol and triglycerides in $\mathrm{mg} / \mathrm{dl}$, respectively. "As determined by $1 \%$ agarose electrophoresis of the $d<1.006 \mathrm{~g} / \mathrm{ml}$ fraction. "Each allele is indicated; $N$, normal apo-E3.

sessed by agarose electrophoresis (data now shown) was similar to that of corresponding fractions from the typical dys- $\beta$ subjects studied previously (27). The total $d<1.006 \mathrm{~g} / \mathrm{ml}$ fractions in all dys $\beta$ subjects contained a prominent $\beta$-migrating band and a less prominent pre- $\beta$-migrating band. The pre- $\beta$ VLDL predominated in the $S_{\mathrm{f}}>100$ fraction, whereas the $\beta$-VLDL predominated in the $S_{\mathrm{f}} 20-60$ fraction. Using agarose electrophoresis, the $d<1.006-\mathrm{g} / \mathrm{ml}$ lipoproteins from atypical and typical dys- $\beta$ subjects were indistinguishable. Subject 13 was included in the study because he had had a dys- $\beta$ profile. However, at the time of this study, he had a type $\mathrm{V}$ profile, as determined by agarose electrophoresis and analytical ultracentrifugation (data not shown).

The chemical compositions and calculated average molecular weights of the $d<1.006 \mathrm{~g} / \mathrm{ml}$ lipoproteins are listed in Table II. These data are similar to those for corresponding

Table II. Composition* and Size of $d<1.006 \mathrm{~g} / \mathrm{ml}$ Fractions

\begin{tabular}{|c|c|c|c|c|c|c|c|c|}
\hline Subject & Sample & Protein & $\begin{array}{c}\text { Free } \\
\text { cholesterol }\end{array}$ & $\begin{array}{c}\text { Cholesteryl } \\
\text { ester }\end{array}$ & Triglyceride & Phospholipid & Diameter ${ }^{\ddagger}$ & $\begin{array}{c}\text { Molecular } \\
\text { weight }\end{array}$ \\
\hline & & & & & & & $n m$ & $\times 10^{6}$ \\
\hline \multicolumn{9}{|c|}{ Apo-E substitution $-\operatorname{Arg}_{142} \rightarrow$ Cys } \\
\hline 3 & $\beta$-VLDL & $6.33 \pm 1.0$ & 10.5 & 32.6 & 35.9 & $14.7 \pm 0.58$ & $29 \pm 5.2$ & 7.8 \\
\hline 3 & Pre- $\beta$-VLDL & $7.45 \pm 2.0$ & 11.4 & 13.9 & 50.3 & $17.0 \pm 2.2$ & $48 \pm 12$ & 34 \\
\hline 4 & $S_{f} 20-60$ & $8.80 \pm 0.42$ & 13.6 & 26.8 & $27.8 \pm 1.4$ & 23.0 & $31 \pm 3.8$ & 9.3 \\
\hline 4 & $S_{f} 60-100$ & $5.94 \pm 0.16$ & 11.4 & 22.1 & $41.1 \pm 1.3$ & $19.4 \pm 3.8$ & $41 \pm 3.1$ & 22 \\
\hline 4 & $S_{f}>100$ & $3.71 \pm 0.2$ & 7.74 & 25.2 & $50.3 \pm 6.9$ & $13.0 \pm 1.3$ & $54 \pm 7.4$ & 47 \\
\hline \multicolumn{9}{|c|}{ Apo-E substitution $-\operatorname{Arg}_{145} \rightarrow$ Cys } \\
\hline 12 & $\beta$-VLDL & $8.25 \pm 0.77$ & 15.3 & 20.2 & $36.0 \pm 1.1$ & $20.3 \pm 3.4$ & $31 \pm 6.3$ & 9.7 \\
\hline 12 & Pre- $\beta$-VLDL & $6.28 \pm 0.23$ & 4.24 & 12.6 & $65.7 \pm 2.9$ & 11.2 & $45 \pm 11$ & 28 \\
\hline 12 & $S_{f} 20-60$ & $10.4 \pm 0.27$ & 9.70 & 26.6 & $35.0 \pm 3.0$ & $18.3 \pm 2.2$ & $30 \pm 3.3$ & 8.8 \\
\hline 12 & $S_{f} 60-100$ & $7.75 \pm 0.28$ & 8.22 & 24.5 & $43.6 \pm 3.5$ & $15.9 \pm 1.9$ & $42 \pm 5.1$ & 23 \\
\hline 12 & $S_{\mathrm{f}}>100$ & $6.94 \pm 0.11$ & 7.55 & 25.7 & $46.2 \pm 2.9$ & $13.6 \pm 1.8$ & $49 \pm 8.7$ & 37 \\
\hline \multicolumn{9}{|c|}{ Apo-E substitution - Lys $_{146} \rightarrow$ Gln $^{\S}$} \\
\hline 13 & $\beta$-fraction & $6.50 \pm 0.00$ & 8.47 & 11.6 & $54.5 \pm 2.9$ & $18.9 \pm 5.9$ & $47 \pm 8.1$ & 32 \\
\hline 13 & Pre- $\beta$-fraction & $6.00 \pm 0.37$ & 6.06 & 7.37 & $69.4 \pm 7.3$ & $11.1 \pm 2.8$ & $52 \pm 10$ & 43 \\
\hline
\end{tabular}

* Percent dry weight of two or three measurements \pm SD. ${ }^{\ddagger}$ Diameter of 100 particles \pm SD. ${ }^{\S}$ Since no distinct $\beta$-VLDL were found in this subject, the more $\beta$-migrating fraction and more pre- $\beta$-migrating fractions isolated by Pevikon block electrophoresis were studied. 
A. Whole VLDL

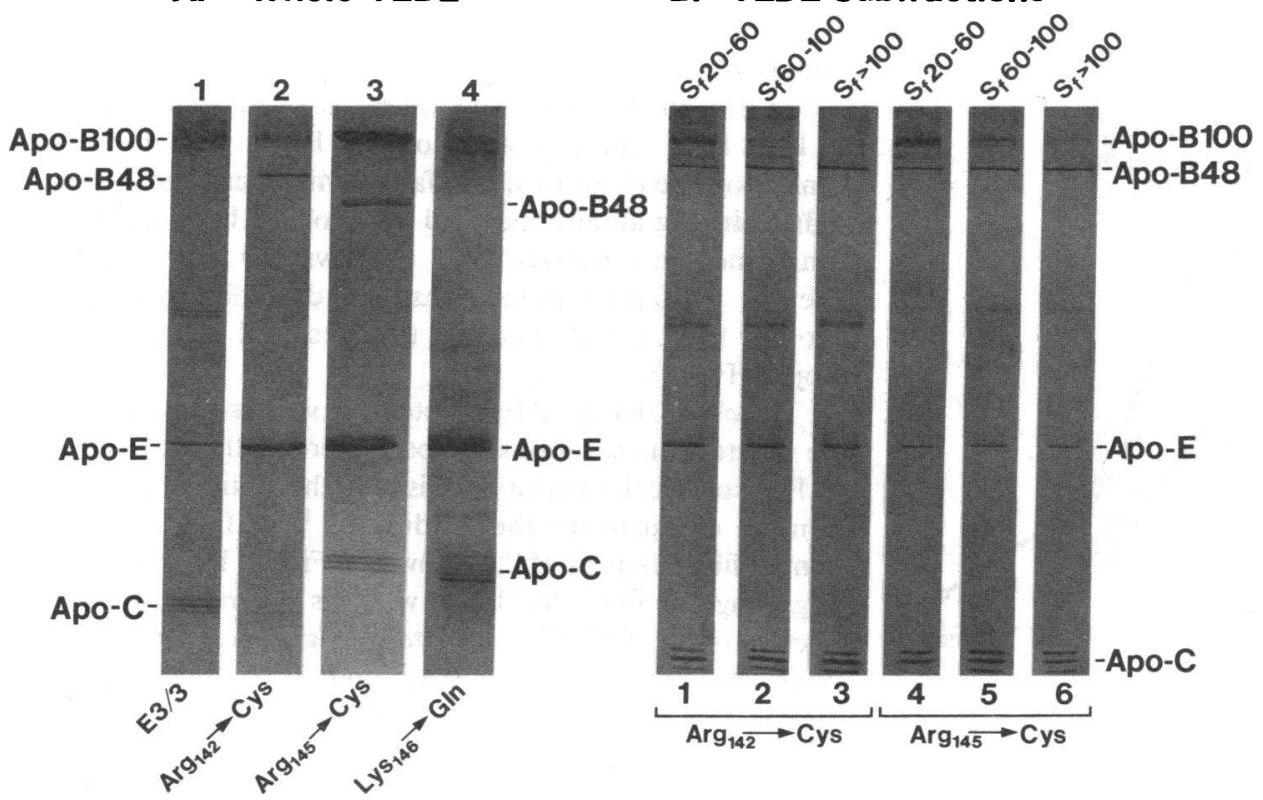

Figure 1. 5-20\% SDS-PAGE of $d$ $<1.006 \mathrm{~g} / \mathrm{ml}$ fractions. Samples were reduced with 0.05 M DTT. ( $A$, lanes 1-4) The Coomassie bluestained total $d<1.006 \mathrm{~g} / \mathrm{ml}$ lipoproteins from subject 7 (homozygous for normal apo-E3), dys- $\beta$ subject 3 (heterozygous for the $\operatorname{Arg}_{142} \rightarrow$ Cys substitution in apo-E), dys- $\beta$ subject 11 (homozygous for the $\operatorname{Arg}_{145} \rightarrow$ Cys substitution in apo-E), and dys- $\beta$ subject 13 (heterozygous for the Lys $_{146} \rightarrow$ Gln substitution in apo-E), respectively. $(B$, lanes 1,2 and 3$)$ The silverstained $S_{\mathrm{f}} 20-60, S_{\mathrm{f}} 60-100$, and $S_{\mathrm{f}}$ $>100$ fractions, respectively, from dys- $\beta$ subject 3 (heterozygous for the $\operatorname{Arg}_{142} \rightarrow$ Cys substitution in apo-E). Lanes 4, 5, and 6 are the silver-stained $S_{\mathrm{f}} 20-60, S_{\mathrm{f}} 60-100$, and $S_{\mathrm{f}}>100$ fractions, respectively, from subject 12 (homozygous for the $\mathrm{Arg}_{145} \rightarrow$ Cys substitution in apo-E). lipoproteins from typical dys- $\beta$ subjects reported previously (27). The pre- $\beta$-VLDL were larger and more triglyceride-rich than the smaller, more cholesteryl ester-rich $\beta$-VLDL. The average calculated density of the pre- $\beta$-VLDL $(0.977 \mathrm{~g} / \mathrm{ml})$ was less than that of the $\beta$-VLDL $(0.994 \mathrm{~g} / \mathrm{ml})$. The chemical compositions and molecular weights of the $S_{f}>100, S_{f} 60-100$, and $S_{\mathrm{f}} 20-60$ fractions reflected their content of pre- $\beta$-VLDL and $\beta$-VLDL.

The relative apolipoprotein content of the $d<1.006 \mathrm{~g} / \mathrm{ml}$ fractions was estimated by scanning densitometry of SDS- polyacrylamide gel electrophoretograms (Fig. 1 and Table III). In Fig. $1 A$, the $d<1.006 \mathrm{~g} / \mathrm{ml}$ fraction from representative dys- $\beta$ subjects had relatively more apo-E and apo-B48 (lanes 2 and 3 ) than did members of family $\mathrm{A}$. without dysbetalipoproteinemia (lane 1). The $S_{\mathrm{f}} 20-60, S_{\mathrm{f}} 60-100$, and $S_{\mathrm{f}}>100$ fractions from representative dys- $\beta$ subjects also had increased amounts of apo-E and apo-B48 (Fig. $1 B$ and Table III) relative to the unaffected subjects. The $d<1.006 \mathrm{~g} / \mathrm{ml}$ lipoprotein fractions from atypical dys $-\beta$ subjects had higher apo-E to total apo-C $(E: C)$ ratios than those found in corresponding lipopro-

Table III. Scanning Densitometry of SDS-PAGE (Coomassie Blue-Stained)*

\begin{tabular}{|c|c|c|c|c|c|}
\hline Subject & Apo- $E^{\ddagger}$ & Sample & E:C ratio & B:E + C ratio" & B48:B 100 ratio' \\
\hline \multicolumn{6}{|l|}{ Atypical dys- $\beta$} \\
\hline 3 & $\operatorname{Arg}_{142} \rightarrow$ Cys & $d<1.006 \mathrm{~g} / \mathrm{ml}$ & $6.7 \pm 2.9$ & $0.98 \pm 0.33$ & $0.15 \pm 0.09$ \\
\hline 3 & $\operatorname{Arg}_{142} \rightarrow$ Cys & $S_{\mathrm{f}}>100$ & 3.9 & 0.28 & 0.58 \\
\hline 3 & $\operatorname{Arg}_{142} \rightarrow$ Cys & $S_{f} 60-100$ & 2.5 & 0.39 & 0.15 \\
\hline 3 & $\operatorname{Arg}_{142} \rightarrow \mathrm{Cys}$ & $S_{f} 20-60$ & 6.6 & 0.90 & 0.05 \\
\hline 11 & $\operatorname{Arg}_{145} \rightarrow$ Cys & $d<1.006 \mathrm{~g} / \mathrm{ml}$ & 6.5 & 1.5 & 0.15 \\
\hline 11 & $\operatorname{Arg}_{145} \rightarrow$ Cys & $S_{\mathrm{f}}>100$ & 11 & 0.36 & 1.3 \\
\hline 11 & $\operatorname{Arg}_{145} \rightarrow$ Cys & $S_{\mathrm{f}} 60-100$ & 6.7 & 0.57 & 0.33 \\
\hline 11 & $\operatorname{Arg}_{145} \rightarrow$ Cys & $S_{\mathrm{f}} 20-60$ & 7.7 & 1.9 & 0.10 \\
\hline 13 & Lys $_{146} \rightarrow$ Gln & $d<1.006 \mathrm{~g} / \mathrm{ml}$ & 3.1 & 0.76 & - \\
\hline \multicolumn{6}{|c|}{ Family members without dys- $\beta$} \\
\hline $7-8$ & Normal & $d<1.006 \mathrm{~g} / \mathrm{ml}$ & 0.61 & 0.98 & - \\
\hline \multicolumn{6}{|l|}{ Typical dys- $\beta$} \\
\hline$n=3$ & 158 & $d<1.006 \mathrm{~g} / \mathrm{ml}$ & $2.1 \pm 1.6$ & $1.2 \pm 0.52$ & $0.06 \pm 0.01$ \\
\hline \multicolumn{6}{|c|}{ Cholesterol-fed rabbit } \\
\hline$n=1$ & - & $d<1.006 \mathrm{~g} / \mathrm{ml}$ & 12 & 0.76 & 0.08 \\
\hline
\end{tabular}

* SDS-PAGE of lipoproteins from typical dys- $\beta$ subjects that were previously reported (27) were scanned again. The same instrument was used to obtain all of the ratios shown. Ratios are given \pm SD where appropriate. ${ }^{\ddagger}$ Amino acid substitution in apo-E. ${ }^{\S}$ Ratio of apo-E to total apo-C. "Ratio of total apo-B (apo-B48 and apo-B100) to apo-E and apo-C. 'No value is given if the ratio of apo-B48 to apo-B100 was too low to measure. 


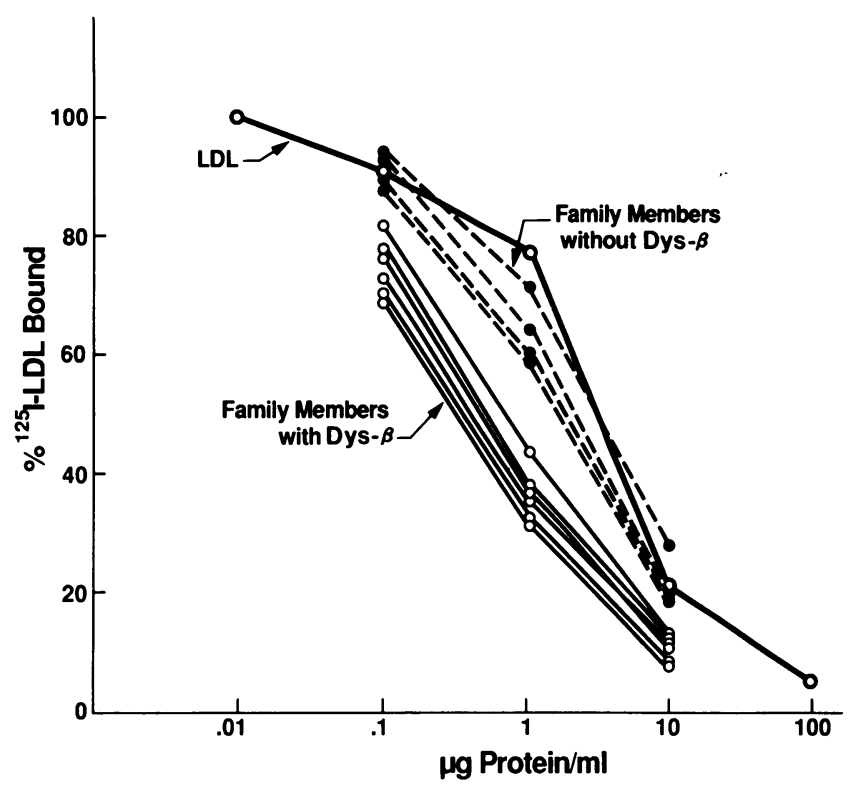

Figure 2. Competition of $d<1.006 \mathrm{~g} / \mathrm{ml}$ lipoproteins for ${ }^{125} \mathrm{I}-\mathrm{LDL}$ binding to cultured human fibroblasts at $4^{\circ} \mathrm{C}$. The ability of lipoproteins at various concentrations to compete for the binding of ${ }^{125} \mathrm{I}$ $\mathrm{LDL}$ at $2 \mu \mathrm{g}$ of protein/ml was determined in duplicate. Fibroblasts were prepared as described under Methods. (Dashed line, closed circles) $d<1.006 \mathrm{~g} / \mathrm{ml}$ lipoproteins from members of family A without dys- $\beta$ (subjects 7-10). (Solid line, open circles) Data from members of family $A$. with dys- $\beta$ who had a substitution in apo-E at residue 142 (subjects 1-6). (Bold line, open circles) LDL from a normal subject.

teins from typical dys- $\beta$ subjects (Table III). A band with the same apparent molecular weight as did albumin was present in some samples (Fig. 1).

Binding of $d<1.006 \mathrm{~g} / \mathrm{ml}$ fractions to the apo- $B, E(L D L)$ receptor. The affinity of the $d<1.006 \mathrm{~g} / \mathrm{ml}$ fractions for the apo-B,E(LDL) receptor on human fibroblasts was determined by the ability of various concentrations of unlabeled lipoproteins to compete for the binding of ${ }^{125} \mathrm{I}-\mathrm{LDL}$ at $4{ }^{\circ} \mathrm{C}$. As a control for interassay variation, the affinity of unlabeled human LDL was measured in each assay. The concentration of unlabeled LDL that resulted in 50\% competition for the binding of ${ }^{125} \mathrm{I}-\mathrm{LDL}\left(\mathrm{EC}_{50}\right)$ was $2.58 \pm 0.15 \mu \mathrm{g}$ of protein $/ \mathrm{ml}$ $(\sim 4.5 \mathrm{nM})$ for $12 \mathrm{LDL}$ preparations in 18 separate assays.

Data from family A. are shown in Fig. 2 . The $d<1.006$ $\mathrm{g} / \mathrm{ml}$ lipoproteins from dys- $\beta$ family members had fourfold higher binding affinity than did lipoproteins from unaffected family members (average $\mathrm{EC}_{50}=0.5$ vs. $2.0 \mu \mathrm{g}$ protein $/ \mathrm{ml}$ ). The $d<1.006 \mathrm{~g} / \mathrm{ml}$ lipoproteins from dys- $\beta$ family members also had fivefold higher affinity than did LDL from a normal subject (Fig. 2).

The $d<1.006 \mathrm{~g} / \mathrm{ml}$ lipoproteins from dys- $\beta$ subjects with the different substitutions in apo-E were further fractionated by Pevikon block electrophoresis, and the ability of these fractions to compete for the binding of ${ }^{125} \mathrm{I}-\mathrm{LDL}$ to cultured human fibroblasts at $4{ }^{\circ} \mathrm{C}$ is shown in Fig. 3. The most pre- $\beta$ migrating fraction is labeled 4 , whereas the most $\beta$-migrating fraction is labeled 1 . The cholesterol/triglyceride ratios of fractions $1-4$ were $1.21,0.82,0.35$, and 0.19 , respectively. Although minor differences are apparent in Fig. $3 A$, each of these fractions had higher affinity for apo-B,E(LDL) receptors than did normal LDL. Similarly, pre- $\beta$-migrating and $\beta$-migrating fractions isolated by Pevikon block electrophoresis of $d$ $<1.006-\mathrm{g} / \mathrm{ml}$ lipoproteins from subjects with the $\mathrm{Arg}_{145} \rightarrow$ Cys or Lys $_{146} \rightarrow$ Gln substitution in apo-E also had higher affinity than did LDL for apo-B,E(LDL) receptors (Fig. 3, $B$ and $C$, respectively).

The ability of the $S_{\mathrm{f}}>100, S_{\mathrm{f}} 60-100$, and $S_{\mathrm{f}} 20-60$ fractions to compete for the binding of ${ }^{125} \mathrm{I}-\mathrm{LDL}$ to fibroblasts at $4^{\circ} \mathrm{C}$ is shown in Fig. 4. Each of these fractions, whether isolated from subjects with an amino acid substitution in apo-E at residue 142,145 , or 146, had higher affinity for apo-B,E(LDL) receptors than did LDL from normal subjects (Fig. 4, $A-C$, respectively). Thus, all of the $d<1.006 \mathrm{~g} / \mathrm{ml}$ lipoproteins from atypical dys- $\beta$ subjects (fractionated by either Pevikon block electrophoresis or sequential ultracentrifugal flotation) had higher receptor binding affinity.

The binding affinities of $d<1.006 \mathrm{~g} / \mathrm{ml}$ fractions to receptors on fibroblasts are summarized in Table IV. Subjects 1-10

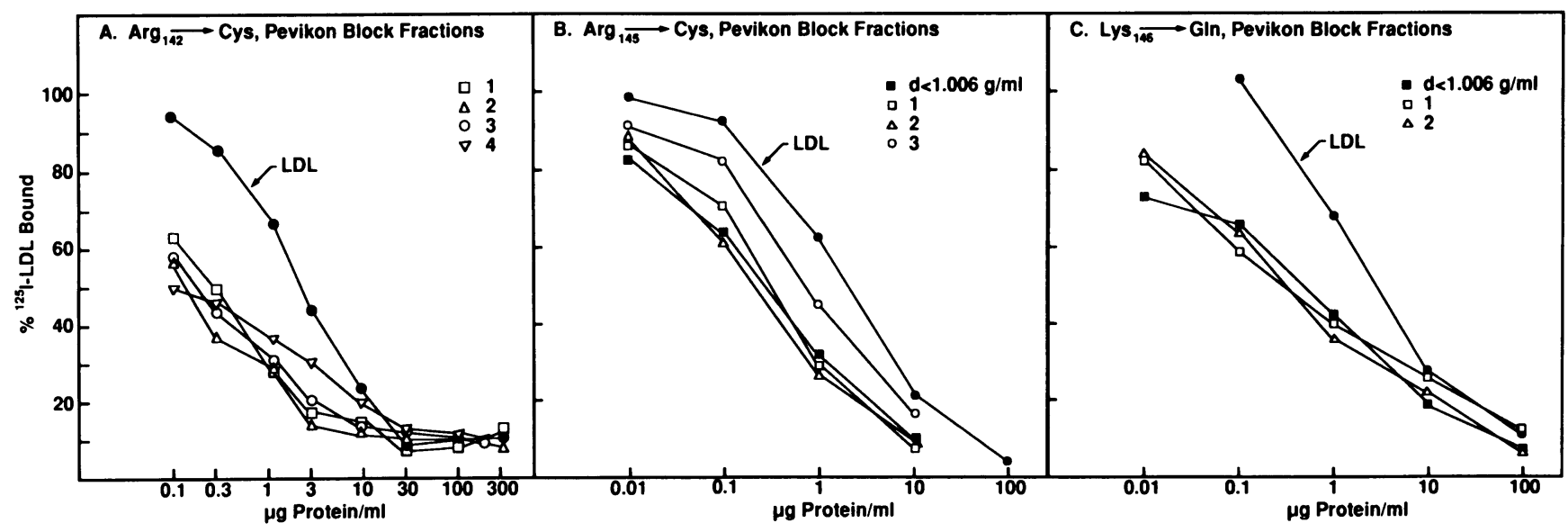

Figure 3. Competition of Pevikon block fractions of the $d<1.006 \mathrm{~g} / \mathrm{ml}$ lipoproteins for the binding of ${ }^{125} \mathrm{I}$-LDL to cultured human fibroblasts at $4{ }^{\circ} \mathrm{C}$. The most $\beta$-migrating fraction is labeled 1 and more pre- $\beta$-migrating fractions are labeled 2,3 , and 4 , respectively. $(A, B$, and $C$ ) Pevikon block fractions from dys- $\beta$ subjects 3,11 , and 13 , respectively, whose apo-E had a substitution at residue 142,145 , or 146, respectively. (B and $C$ ) The binding of the total $d<1.006 \mathrm{~g} / \mathrm{ml}$ fraction is also shown. The competition of LDL from a normal donor is shown in each panel. 


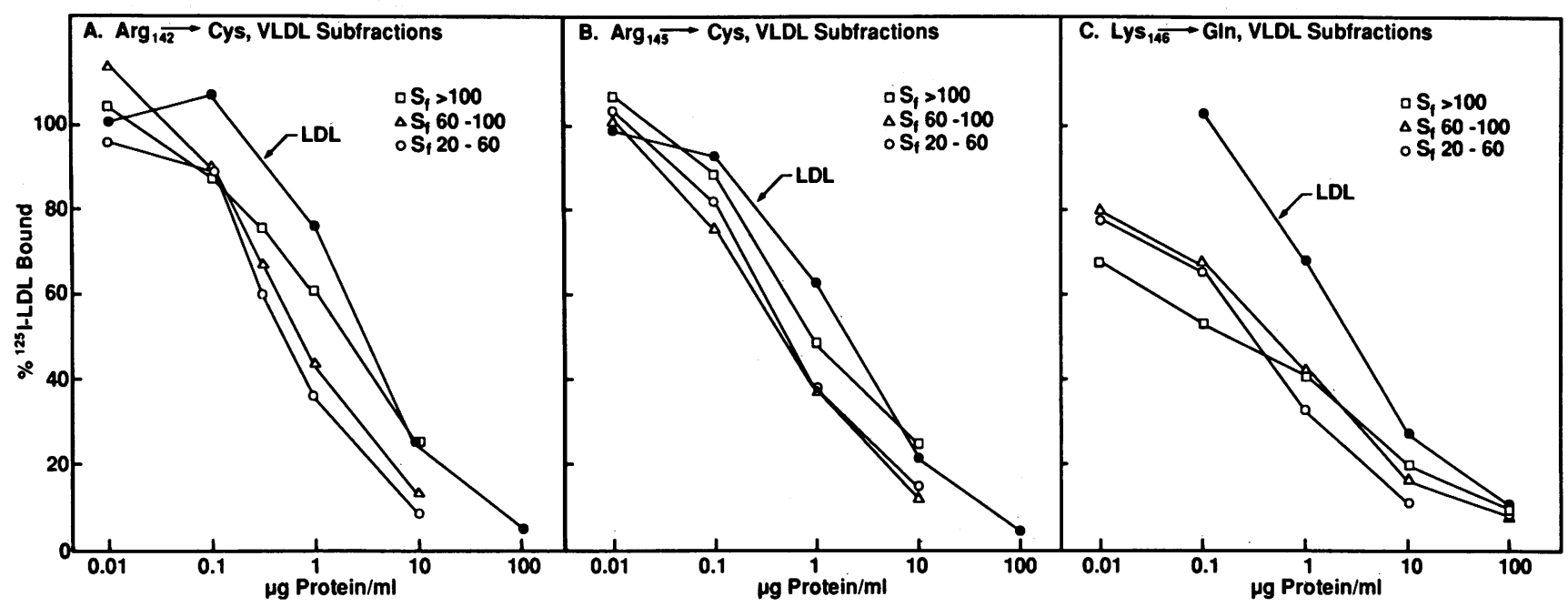

Figure 4. Competition of $\mathrm{S}_{\mathrm{f}}>100, \mathrm{~S}_{\mathrm{f}} 60-100$, and $\mathrm{S}_{\mathrm{f}} 20-60$ fractions for the binding of ${ }^{125} \mathrm{I}-\mathrm{LDL}$ to cultured human fibroblasts at $4^{\circ} \mathrm{C}$. $(A, B$, and $C$ ) Competition of these lipoproteins from dys- $\beta$ subjects 4,11 , and 13 , respectively, whose apo-E had a substitution at residue 142, 145, or 146 , respectively.

were studied on two to four separate occasions; the plasma from the other subjects was obtained once. Pre- $\beta$-VLDL had slightly lower affinity than did $\beta$-VLDL (average $\mathrm{EC}_{50}=0.76$ versus $0.46 \mu \mathrm{g}$ of protein $/ \mathrm{ml}$, respectively). Likewise, the $S_{\mathrm{f}}$ $>100$ fraction, which was relatively enriched in pre- $\beta$-VLDL, had lower binding affinity than did the $S_{\mathrm{f}} 20-60$ fraction, in which $\beta$-VLDL predominated (average $\mathrm{EC}_{50}=1.1 \mathrm{vs} .0 .44 \mu \mathrm{g}$ of protein $/ \mathrm{ml}$ ). In members of family $A$. who did not have dysbetalipoproteinemia (subjects $7-10$ ), the more $\beta$-migrating fraction of the $d<1.006 \mathrm{~g} / \mathrm{ml}$ lipoproteins had fourfold higher affinity than the more pre- $\beta$-migrating fraction (average $\mathrm{EC}_{50}$ $=1.1$ vs. $4.3 \mu \mathrm{g}$ of protein $/ \mathrm{ml}$ ). When binding affinities were expressed on a molar basis using molecular weights from Table II, the average $\mathrm{EC}_{50}$ of lipoproteins from representative atypical dys- $\beta$ subjects was $0.4 \mathrm{nM}$ for pre- $\beta$-VLDL and $0.5 \mathrm{nM}$ for $\beta$-VLDL. The $\mathrm{EC}_{50}$ of $\mathrm{S}_{\mathrm{f}}>100, \mathrm{~S}_{\mathrm{f}} 60-100$, and $\mathrm{S}_{\mathrm{f}} 20-60$ fractions from dys- $\beta$ subjects with a substitution in apo-E at residue 142 or 145 was $0.4-0.6 \mathrm{nM}$. Thus, the high affinity of

Table IV. Receptor Binding Affinities* of $d<1.006 \mathrm{~g} / \mathrm{ml}$ Fractions

\begin{tabular}{|c|c|c|c|c|c|c|c|}
\hline Subject & Apo-E $E^{\ddagger}$ & $d<1.006 \mathrm{~g} / \mathrm{ml}$ & Pre- $\beta$-VLDL & $\beta$-VLDL & $\mathrm{S}_{\mathrm{f}}>100$ & $S_{\mathrm{f}} 60-100$ & $S_{\mathrm{r}} 20-60$ \\
\hline \multicolumn{8}{|c|}{ Atypical dys $-\beta$} \\
\hline $1-6$ & 142 & $\begin{array}{c}0.50 \pm 0.14 \\
(n=14)\end{array}$ & $\begin{array}{c}0.47 \pm 0.19 \\
(n=6)\end{array}$ & $\begin{array}{c}0.42 \pm 0.16 \\
(n=6)\end{array}$ & $\begin{array}{l}1.4 \pm 0.15 \\
(n=6)\end{array}$ & $\begin{array}{c}0.75 \pm 0.11 \\
(n=6)\end{array}$ & $\begin{array}{c}0.48 \pm 0.11 \\
(n=4)\end{array}$ \\
\hline $11-12$ & 145 & $\begin{array}{c}0.44 \pm 0.05 \\
(n=4)\end{array}$ & $\begin{array}{c}1.60 \pm 0.24 \\
(n=4)\end{array}$ & $\begin{array}{c}0.41 \pm 0.04 \\
(n=4)\end{array}$ & $\begin{array}{l}1.2 \pm 0.17 \\
(n=4)\end{array}$ & $\begin{array}{c}0.58 \pm 0.14 \\
(n=4)\end{array}$ & $\begin{array}{c}0.43 \pm 0.12 \\
(n=4)\end{array}$ \\
\hline $13^{\S}$ & 146 & $\begin{array}{c}0.43 \\
(n=2)\end{array}$ & $\begin{array}{c}0.71 \\
(n=2)\end{array}$ & $\begin{array}{c}0.72 \\
(n=2)\end{array}$ & $\begin{array}{c}0.64 \\
(n=2)\end{array}$ & $\begin{array}{c}0.61 \\
(n=2)\end{array}$ & $\begin{array}{c}0.41 \\
(n=2)\end{array}$ \\
\hline Mean & & $\begin{array}{c}0.48 \pm 0.13 \\
(n=20)\end{array}$ & $\begin{array}{c}0.76 \pm 0.23 \\
(n=12)\end{array}$ & $\begin{array}{c}0.46 \pm 0.15 \\
(n=12)\end{array}$ & $\begin{array}{l}1.1 \pm 0.16 \\
(n=12)\end{array}$ & $\begin{array}{c}0.67 \pm 0.12 \\
(n=12)\end{array}$ & $\begin{array}{c}0.44 \pm 0.11 \\
(n=10)\end{array}$ \\
\hline \multicolumn{8}{|c|}{ Family A. members without dys- $\beta^{\wp}$} \\
\hline $7-10$ & Normal & $\begin{array}{l}2.0 \pm 0.14 \\
(n=8)\end{array}$ & $\begin{array}{l}4.3 \pm 0.15 \\
(n=4)\end{array}$ & $\begin{array}{l}1.1 \pm 0.12 \\
(n=4)\end{array}$ & & & \\
\hline \multicolumn{8}{|c|}{ Typical dys- $\beta$} \\
\hline & $158^{\prime \prime}$ & & $\begin{array}{c}490 \pm 200 \\
(n=10)\end{array}$ & $\begin{array}{l}8.0 \pm 3.3 \\
(n=18)\end{array}$ & $\begin{array}{l}370 \pm 150 \\
(n=3)\end{array}$ & $\begin{array}{c}62 \pm 16 \\
(n=5)\end{array}$ & $\begin{array}{l}7.8 \pm 3.5 \\
(n=5)\end{array}$ \\
\hline \multicolumn{8}{|c|}{ Cholesterol-fed animals } \\
\hline Rabbit & - & $0.42(n=1)$ & $0.38(n=1)$ & $2.1(n=1)$ & & & \\
\hline Dog & - & $0.27(n=2)$ & $0.05(n=2)$ & $0.36(n=2)$ & & & \\
\hline
\end{tabular}

${ }^{*} \mathrm{EC}_{50}$ expressed as $\mu \mathrm{g}$ protein $/ \mathrm{ml} \pm \mathrm{SD}$. Values in parentheses are the number of separate binding assays. ${ }^{\ddagger}$ Site of amino acid substitution in apo-E. ${ }^{\S}$ Since no definite $\beta$-VLDL were found, values shown are for the more pre- $\beta$-migrating and more $\beta$-migrating fractions isolated by Pevikon block electrophoresis. "Values shown from typical dys- $\beta$ subjects have been reported previously (27). 
these lipoproteins compared with that of $\operatorname{LDL}\left(\mathrm{EC}_{50}=4.5 \mathrm{nM}\right)$ was apparent when binding affinity was expressed on a molar basis.

In an effort to avoid artifacts associated with the isolation of lipoproteins, receptor binding studies using whole plasma were performed (Fig. 5). Fresh whole plasma was studied on two consecutive days. Whole plasma from atypical dys- $\beta$ subjects 3 or 4 had, on average, sevenfold higher receptor binding affinity than did the whole plasma from two normolipidemic $\mathrm{E} 3 / 3$ subjects; $\mathrm{EC}_{50}=14 \mathrm{vs}$. $100 \mu \mathrm{g}$ protein $/ \mathrm{ml}$ (average of two experiments). These data reflect the average receptor binding affinity of all lipoproteins in the whole plasma and showed that the average affinity of lipoproteins in atypical dys- $\beta$ plasma was higher than that in normal plasma.

Apolipoprotein $\mathrm{E}$ was responsible for the majority of the binding of all $d<1.006 \mathrm{~g} / \mathrm{ml}$ lipoprotein fractions to the apo-B,E(LDL) receptor. Monoclonal antibodies 4G3 and MB47, which specifically block apo-B100-mediated binding, inhibited $0-35 \%$ of the binding of the ${ }^{125} \mathrm{I}-\mathrm{VLDL}$ subfractions studied (i.e., pre- $\beta$-VLDL, $\beta$-VLDL, and the $\mathrm{S}_{\mathrm{f}}>100, \mathrm{~S}_{\mathrm{f}}$ $60-100$, and $S_{f} 20-60$ fractions). However, these antibodies inhibited $>90 \%$ of ${ }^{125} \mathrm{I}-\mathrm{LDL}$ binding. In contrast, monoclonal antibody 1D7, which specifically inhibits apo-E-mediated binding, inhibited $60-90 \%$ of the binding of the ${ }^{125} \mathrm{I}-\mathrm{VLDL}$ subfractions. Comparison of $S_{f}>100$ and $S_{f} 20-60$ fractions showed no shift from apo-E-mediated to apo-B100-mediated binding. These studies were performed on two or more separate occasions and used pre- $\beta$-VLDL, $\beta$-VLDL, $\mathrm{S}_{\mathrm{f}}>100, \mathrm{~S}_{\mathrm{f}}$ $60-100$, or $S_{\mathrm{f}} 20-60$ fractions from subjects 3,4 , and 12 who had a substitution in their apo-E at residue 142 or 145.

Studies in cholesterol-fed rabbits and cholesterol-fed dogs. Cholesterol-fed rabbits and cholesterol-fed dogs are animal models in which there is $\beta$-VLDL accumulation. However, they do not have a mutation in apo-E. The animals studied had plasma cholesterol concentrations of over $1,000 \mathrm{mg} / \mathrm{dl}$. The binding of Pevikon block fractions of $d<1.006 \mathrm{~g} / \mathrm{ml}$

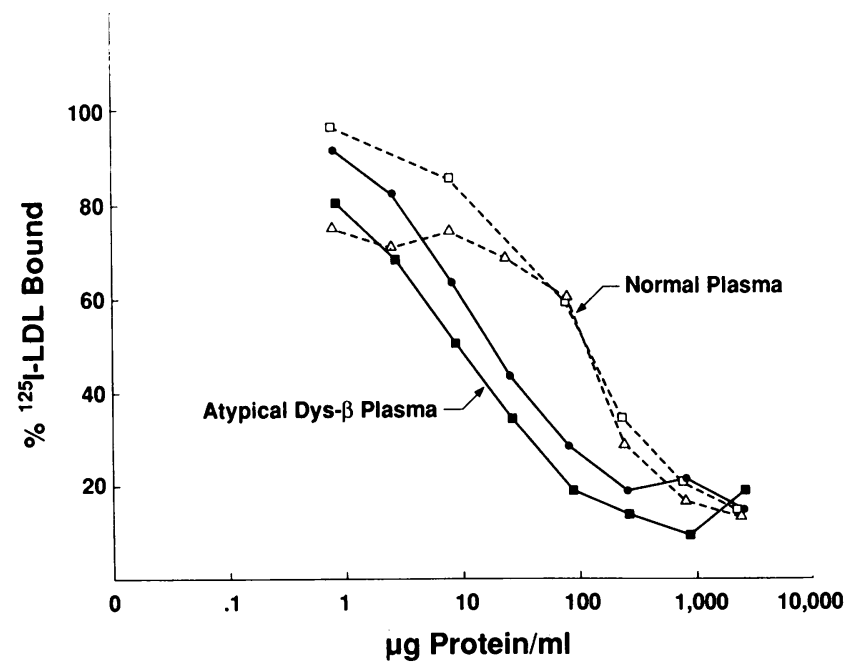

Figure 5. Competition of whole plasma for the binding of human ${ }^{125} \mathrm{I}$-LDL to fibroblasts at $4^{\circ} \mathrm{C}$. Fresh whole plasma (containing 1 $\mathrm{mg} / \mathrm{ml}$ EDTA, sodium salt) from atypical dys- $\beta$ subject 3 ( $\bullet, \mathrm{EC}_{50}$ $=7.5 \mu \mathrm{g}$ protein $/ \mathrm{ml})$, atypical dys $\beta$ subject $4\left(\bullet, \mathrm{EC}_{50}=12.6 \mu \mathrm{g}\right.$ protein $/ \mathrm{ml}$, or normolipidemic $\mathrm{E} 3 / 3$ subjects $\left(\triangle, \mathrm{EC}_{50}=83 \mu \mathrm{g}\right.$ protein/ $\mathrm{ml}$ or $\square, \mathrm{EC}_{50}=97 \mu \mathrm{g}$ protein $/ \mathrm{ml}$ ) was used in the concentrations indicated. lipoproteins from cholesterol-fed rabbits and cholesterol-fed dogs is shown in Fig. 6, $A$ and $B$, respectively. Rabbit Pevikon block fractions 1-3 had cholesterol/triglyceride ratios of 6.4 , 3.5 , and 0.76 , respectively, whereas the corresponding canine fractions had cholesterol/triglyceride ratios of 20,15 , and 8 , respectively. Thus, $d<1.006-\mathrm{g} / \mathrm{ml}$ lipoproteins from cholesterol-fed animals were, on the whole, much more cholesterolrich than those from human dys- $\beta$ subjects. They were also rich in apo-E as shown by their E:C ratio (Table III). All Pevikon block fractions had higher binding affinity for human apo-B,E(LDL) receptors than did human $L D L$ and were similar in binding affinity to corresponding fractions from human atypical dys- $\beta$ subjects (Table IV).

\section{Discussion}

The association of familial dysbetalipoproteinemia (type III hyperlipoproteinemia) with amino acid substitutions in apo-E that cause defective binding to apo-B,E(LDL) receptors is well established $(1,5,13)$. It has been known for several years that the degree of defective receptor binding of the various apo-E mutants may be nearly normal or severely defective and does not correlate with the severity of dysbetalipoproteinemia (1, 6, 13). Nevertheless, since all amino acid substitutions in apo-E that are associated with dysbetalipoproteinemia cause at least some decreased binding to receptors, it was reasonable to suspect that native lipoproteins containing these apo-E mutants would have defective binding as well. Therefore, the finding that $d<1.006 \mathrm{~g} / \mathrm{ml}$ lipoproteins from atypical dys- $\beta$ subjects had higher binding affinity than did $d<1.006 \mathrm{~g} / \mathrm{ml}$ lipoproteins from normal subjects was surprising. On the other hand, since apo-E from the atypical dys- $\beta$ subjects had higher affinity than apo-E from typical dys- $\beta$ subjects, it was not surprising that their $d<1.006 \mathrm{~g} / \mathrm{ml}$ lipoproteins also had higher binding affinity.

In the current study, dys- $\beta$ subjects with amino acid substitutions in apo-E at atypical sites (residues 142, 145, or 146) were found to have several features in common with typical dys- $\beta$ subjects. In all dys- $\beta$ subjects, the pre- $\beta$-VLDL were larger, had higher flotation rates, and were more triglyceriderich than the smaller, more cholesteryl ester-rich $\beta$-VLDL. The higher B48:B100 ratio in pre- $\beta$-VLDL than in $\beta$-VLDL agrees with other studies in which lipoproteins from the intestine were found to be larger and have higher flotation rates than those from the liver (27, 53-55).

A major difference between typical and atypical dys- $\beta$ subjects was the marked increase in receptor binding affinity of the atypical dys- $\beta d<1.006 \mathrm{~g} / \mathrm{ml}$ lipoproteins. The receptor binding affinities of pre- $\beta$-VLDL and $\beta$-VLDL from atypical dys- $\beta$ subjects were 640 - and 17 -fold higher, respectively, than corresponding lipoproteins from typical dys- $\beta$ subjects (Table IV). Another difference was that pre- $\beta$-VLDL and $\beta$-VLDL from atypical dys- $\beta$ subjects had similar binding affinities, whereas $\beta$-VLDL from typical dys- $\beta$ subjects had over 68 -fold higher affinity than did their pre- $\beta$-VLDL (27). Since both pre- $\beta$-VLDL and $\beta$-VLDL from atypical dys- $\beta$ subjects had high binding affinities, decreased binding affinity of pre- $\beta$ VLDL is not a major factor in the formation of $\beta$-VLDL as may be the case in typical dys- $\beta$ subjects (27).

The $d<1.006 \mathrm{~g} / \mathrm{ml}$ fractions from atypical dys- $\beta$ subjects had higher affinity than did the $d<1.006 \mathrm{~g} / \mathrm{ml}$ fractions from normolipidemic or hyperlipidemic subjects (27) or from unaf- 
fected members of family A. who were homozygous for normal apo-E3. In addition, the receptor binding studies performed using the whole plasma indicate that the average affinity of lipoproteins in atypical dys- $\beta$ subjects is sevenfold higher than in normal subjects (Fig. 5). Thus, it is difficult to conclude that defective interaction of atypical dys- $\beta$ lipoproteins with apo-B,E(LDL) receptors results in delayed clearance in vivo. When these lipoproteins were studied in vivo in cholesterol-fed rabbits, the clearance of ${ }^{125}$ I-labeled apo-B in pre- $\beta$ VLDL and $\beta$-VLDL from an atypical dys- $\beta$ subject was much faster than that of ${ }^{125} \mathrm{I}$-labeled apo-B in corresponding lipoproteins from a typical dys- $\beta$ subject (unpublished observations). However, the clearance of these lipoproteins from the plasma of rabbits may not be the same as the clearance in humans.

What is the mechanism of the high binding affinity of $d$ $<1.006-\mathrm{g} / \mathrm{ml}$ lipoproteins from atypical dys- $\beta$ subjects, and why do lipoproteins with high binding affinity accumulate in subjects with this disorder? First, the amino acid substitutions in apo-E from atypical dys- $\beta$ subjects cause less defective binding to receptors than does the typical substitution at residue $158(1,5,10)$. Second, apo-E on native lipoproteins from subjects who were heterozygous for a substitution in apo-E at residue 142 or 146 was a mixture of both abnormal and normal apo-E. Finally, all $d<1.006 \mathrm{~g} / \mathrm{ml}$ lipoproteins from the atypical dys $-\beta$ subjects contained relatively more apo-E than did corresponding lipoproteins from typical dys- $\beta$ subjects (Table III). The enrichment of these lipoproteins in apo-E probably increased their affinity for apo-B,E(LDL) receptors and may be due to differences in how atypical apo-E isoforms partition among lipoproteins. In other studies, when normal apo-E3 was added to $d<1.006 \mathrm{~g} / \mathrm{ml}$ lipoproteins from subjects with the $\operatorname{Arg}_{142} \rightarrow$ Cys substitution in vitro, these particles acquired a higher binding affinity (56). This suggests that lipoproteins from atypical dys- $\beta$ subjects, despite their high receptor binding affinity, have lower affinity than they would if only normal apo-E3 was present. More detailed analysis is needed to estimate the number of apo-E molecules per particle in both atypical and typical dys- $\beta$ subjects. However, gross differences in lipid composition do not account for the differences in receptor binding affinity observed.

In general, the affinity of lipoproteins for apo-B,E(LDL) receptors on fibroblasts correlates well with their rate of clearance from the plasma (57-60) and therefore cannot explain the accumulation of lipoproteins with high binding affinity in atypical dysbetalipoproteinemia. At least three possible mechanisms could contribute to the accumulation of lipoproteins with high binding affinity in atypical dys- $\beta$ subjects. First, defective apo-B,E(LDL) receptors could cause decreased clearance of lipoproteins despite high binding affinity. This seems unlikely, however, because atypical dys- $\beta$ subjects with the $\operatorname{Arg}_{142} \rightarrow$ Cys substitution in apo-E, in whom receptors on skin fibroblasts have been measured, have no defect in their receptors (10). Second, atypical mutations in apo-E may disrupt some function of apo-E other than that measured by the fibroblast binding assay. The interaction of apo-E with other hepatic lipoprotein receptors or with lipolytic or other modifying enzymes may be important for the normal metabolism of $d$ $<1.006 \mathrm{~g} / \mathrm{ml}$ lipoproteins. In fact, hepatic lipase deficiency alone has been reported to cause severe dysbetalipoproteinemia (61). However, the atypical dys- $\beta$ family members with the $\operatorname{Arg}_{142} \rightarrow$ Cys apo-E substitution have normal postheparin lipase activity (9). A third possibility is that overproduction of lipoproteins and downregulation of apo-B,E(LDL) receptors could cause accumulation of lipoproteins that have high binding affinity. The studies reported here using cholesterol-fed rabbits and cholesterol-fed dogs support this possibility. Apparently, in cholesterol-fed animals, a high-cholesterol and high-fat diet alone is sufficient to overwhelm the ability of apo-E to clear lipoproteins thereby causing the accumulation of $\beta$-VLDL despite the high receptor binding affinity of the diet-induced lipoproteins (Fig. 6 and Table IV).

The only human in vivo study in which atypical and typical dys- $\beta$ subjects have been compared shows that the clearance of apo-B in $d<1.006-\mathrm{g} / \mathrm{ml}$ lipoproteins from dys- $\beta$ subjects with an amino acid substitution in apo-E at 158 or 145 was similarly delayed (32). However, this study did not discriminate between the three mechanisms for $\beta$-VLDL accumulation described above. In the future, studies of in vivo apo-B kinetics of pre- $\beta$-VLDL and $\beta$-VLDL from atypical dys- $\beta$ subjects may be useful to measure the rate of production of these lipoproteins. It is reasonable to speculate that the clearance of LDL in atypical dys- $\beta$ subjects may be slower than it is in typical dys- $\beta$ subjects due to competition for receptor binding by $d<1.006 \mathrm{~g} / \mathrm{ml}$ lipoproteins with higher affinity than that of LDL or due to downregulation of apo-B,E(LDL) receptors. Direct measurement of the interaction between pre- $\beta$-VLDL or $\beta$-VLDL and hepatic tissue may reveal binding sites other than the apo-B,E(LDL) receptor and may also shed light on the pathogenesis of atypical dysbetalipoproteinemia.

A fascinating and unexplained feature of atypical dysbetalipoproteinemia is its apparent inheritance as an autosomal dominant trait in some families $(9-11,62)$. Members of family A. in this study who did not have dysbetalipoproteinemia had a double pre- $\beta$ pattern, and some had hypercholesterolemia (Table I). The trait or traits that caused the double pre- $\beta$ pattern and hypercholesterolemia may have contributed to the expression of dysbetalipoproteinemia. Atypical dys- $\beta$ subjects might have more than one genetic defect; other hyperlipidemic factors might act in combination with abnormal apo-E to cause a dys- $\beta$ profile. If this is so, normolipidemic subjects with atypical mutations in apo-E should exist. Environmental or acquired factors might also affect atypical and typical dys- $\beta$

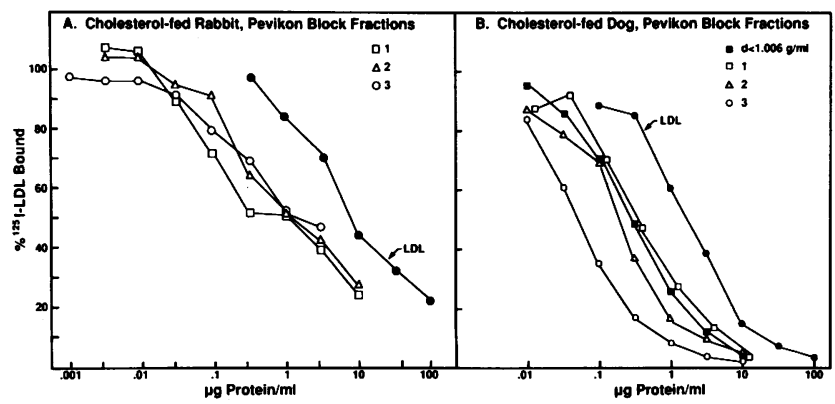

Figure 6. Competition of the Pevikon block fractions of the $d$ $<1.006 \mathrm{~g} / \mathrm{ml}$ lipoproteins from a cholesterol-fed rabbit $(A)$ or cholesterol-fed $\operatorname{dog}(B)$ for the binding of ${ }^{125}$ I-LDL to cultured human fibroblasts at $4^{\circ} \mathrm{C}$. The most $\beta$-migrating fraction is labeled $l$ and more pre- $\beta$-migrating subfractions are labeled 2 and 3 , respectively. $(B)$ The binding of the total $d<1.006 \mathrm{~g} / \mathrm{ml}$ fraction is also shown. The competition of LDL from a normal human subject is shown in each panel. 
subjects differently. More studies are needed to address these issues.

In summary, the major finding in this study is that $d$ $<1.006 \mathrm{~g} / \mathrm{ml}$ lipoproteins from atypical dys- $\beta$ subjects have paradoxically high affinity for apo-B,E(LDL) receptors. The accumulation of $d<1.006 \mathrm{~g} / \mathrm{ml}$ lipoproteins in atypical dys- $\beta$ subjects cannot be ascribed simply to low affinity for apo-B,E(LDL) receptors, as happens in typical dys- $\beta$ subjects. Another explanation for the pathogenesis of atypical dysbetalipoproteinemia must be found. Although cholesterol-fed animals do not have a mutation in apo-E, they may serve as useful models for atypical dysbetalipoproteinemia because they also accumulate $\beta$-VLDL by a mechanism other than decreased affinity of lipoproteins for apo-B,E(LDL) receptors. Since overproduction of $d<1.006 \mathrm{~g} / \mathrm{ml}$ lipoproteins and downregulation of apo-B,E(LDL) receptors in these animals appear to cause the formation of $\beta$-VLDL, a similar mechanism may be important in the pathogenesis of human atypical dysbetalipoproteinemia.

\section{Acknowledgments}

I would like to thank Robert W. Mahley for support; Thomas P. Bersot, Richard J. Havel, and Howard Feigenbaum for assistance with recruitment of human subjects; Maureen Balestra, Glenna Fry, and Michelle Waknitz for assistance with fibroblast binding assays; Linda Anderson and Janet Boyles for assistance with electron microscopy; and Frank $T$. Lindgren and his associates for performing analytical ultracentrifugation. Thanks also to Marlene Blakley for manuscript preparation, Charles Benedict for preparation of the figures, and $\mathrm{Al}$ Averbach and Sally Gullatt Seehafer for editorial assistance.

This work was supported by research grants HL-07216, HL-02024, and HL-14230 from the National Institutes of Health. The human studies were performed in the General Clinical Research Center (RR83) at San Francisco General Hospital, University of California, San Francisco, and were supported by the Division of Research Resources of the National Institutes of Health.

\section{References}

1. Mahley, R. W., and S. C. Rall, Jr. 1989. Type III hyperlipoproteinemia (dysbetalipoproteinemia): the role of apolipoprotein $\mathrm{E}$ in normal and abnormal lipoprotein metabolism. In The Metabolic Basis of Inherited Disease. 6th Edition. C. R. Scriver, A. L. Beaudet, W. S. Sly, and D. Volle, editors. McGraw-Hill Book Co., New York. 1195-1213.

2. Havel, R. J., and J. P. Kane. 1973. Primary dysbetalipoproteinemia: predominance of a specific apoprotein species in triglyceriderich lipoproteins. Proc. Natl. Acad. Sci. USA. 70:2015-2019.

3. Utermann, G., M. Jaeschke, and J. Menzel. 1975. Familial hyperlipoproteinemia type III: deficiency of a specific apolipoprotein (apo E-III) in the very-low-density lipoproteins. FEBS (Fed. Eur. Biochem. Soc.) Lett. 56:352-355.

4. Zannis, V. I., and J. L. Breslow. 1981. Human very low density lipoprotein apolipoprotein $\mathrm{E}$ isoprotein polymorphism is explained by genetic variation and posttranslational modification. Biochemistry. 20:1033-1041.

5. Rall, S. C., Jr., K. H. Weisgraber, T. L. Innerarity, and R. W. Mahley. 1982. Structural basis of receptor binding heterogeneity of apolipoprotein E from type III hyperlipoproteinemic subjects. Proc. Natl. Acad. Sci. USA. 79:4695-4700.

6. Rall, S. C., Jr., K. H. Weisgraber, T. L. Innerarity, R. W. Mahley, and G. Assmann. 1983. Identical structural and receptor binding defects in apolipoprotein E2 in hypo-, normo-, and hypercholesterolemic dysbetalipoproteinemia. J. Clin. Invest. 71:1023-1031.
7. Emi, M., L. L. Wu, R. R. Williams, R. L. White, and J.-M. Lalouel. 1988. Apolipoprotein E genotyping: identification of rare structural mutants of E2 isoform. Circulation. 78:1557. (Abstr.)

8. Rall, S. C., Jr., K. H. Weisgraber, T. L. Innerarity, T. P. Bersot, R. W. Mahley, and C. B. Blum. 1983. Identification of a new structural variant of human apolipoprotein E, E2(Lys s46 $_{14} \rightarrow$ Gln), in a type III hyperlipoproteinemic subject with the E3/2 phenotype. J. Clin. Invest. 72:1288-1297.

9. Havel, R. J., L. Kotite, J. P. Kane, P. Tun, and T. Bersot. 1983. Atypical familial dysbetalipoproteinemia associated with apolipoprotein phenotype E3/3. J. Clin. Invest. 72:379-387.

10. Rall, S. C. Jr., Y. M. Newhouse, H. R. G. Clarke, K. H. Weisgraber, B. J. McCarthy, R. W. Mahley, and T. P. Bersot. 1989. Type III hyperlipoproteinemia associated with apolipoprotein $\mathrm{E}$ phenotype E3/3. Structure and genetics of an apolipoprotein E3 variant. J. Clin. Invest. 83:1095-1101.

11. Havekes, L. M., J. A. G. Leuven, E. van Corven, E. De Wit, and J. J. Emeis. 1984. Functionally inactive apolipoprotein $E_{3}$ in a type III hyperlipoproteinaemic patient. Eur. J. Clin. Invest. 14:7-11.

12. Gregg, R. E., G. Ghiselli, and H. B. Brewer, Jr. 1983. Apolipoprotein $\mathrm{E}_{\text {Bethesda }}$ : a new variant of apolipoprotein $\mathrm{E}$ associated with type III hyperlipoproteinemia. J. Clin. Endocrinol. Metab. 57:969-974.

13. Schneider, W. J., P. T. Kovanen, M. S. Brown, J. L. Goldstein, G. Utermann, W. Weber, R. J. Havel, L. Kotite, J. P. Kane, T. L. Innerarity, and R. W. Mahley. 1981. Familial dysbetalipoproteinemia. Abnormal binding of mutant apoprotein $\mathrm{E}$ to low density lipoprotein receptors of human fibroblasts and membranes from liver and adrenal of rats, rabbits, and cows. J. Clin. Invest. 68:1075-1085.

14. Sing, C. F., and J. Davignon. 1985. Role of the apolipoprotein E polymorphism in determining normal plasma lipid and lipoprotein variation. Am. J. Hum. Gent. 37:268-285.

15. Ehnholm, C., M. Lukka, T. Kuusi, E. Nikkilä, and G. Utermann. 1986. Apolipoprotein E polymorphism in the Finnish population: gene frequencies and relation to lipoprotein concentrations. $J$. Lipid Res. 27:227-235.

16. Menzel, H.-J., R.-G. Kladetzky, and G. Assmann. 1983. Apolipoprotein E polymorphism and coronary artery disease. Arteriosclerosis. 3:310-315.

17. Breslow, J. L., V. I. Zannis, T. R. SanGiacomo, J. L. H. C. Third, T. Tracy, and C. J. Glueck. 1982. Studies of familial type III hyperlipoproteinemia using as a genetic marker the apoE phenotype E2/2. J. Lipid Res. 23:1224-1235.

18. Morganroth, J., R. I. Levy, and D. S. Fredrickson. 1975. The biochemical, clinical, and genetic features of type III hyperlipoproteinemia. Ann. Intern. Med. 82:158-174.

19. Falko, J. M., J. L. Witztum, G. Schonfeld, S. W. Weidman, and J. B. Kolar. 1979. Type III hyperlipoproteinemia. Rise in high-density lipoprotein levels in response to therapy. Am. J. Med. 66:303-310.

20. Hazzard, W. R., and E. L. Bierman. 1972. Aggravation of broad- $\beta$ disease (type 3 hyperlipoproteinemia) by hypothyroidism. Arch. Intern. Med. 130:822-828.

21. Hazzard, W. R., T. F. O'Donnell, and Y. L. Lee. 1975. Broad- $\beta$ disease (type III hyperlipoproteinemia) in a large kindred. Evidence for a monogenic mechanism. Ann. Intern. Med. 82:141-149.

22. Vessby, B., H. Hedstrand, L.-G. Lundin, and U. Olsson. 1977. Inheritance of type III hyperlipoproteinemia. Lipoprotein patterns in first-degree relatives. Metab. Clin. Exp. 26:225-254.

23. Hazzard, W. R., G. R. Warnick, G. Utermann, and J. J. Albers. 1981. Genetic transmission of isoapolipoprotein $E$ phenotypes in a large kindred: relationship to dysbetalipoproteinemia and hyperlipidemia. Metab. Clin. Exp. 30:79-88.

24. Hazzard, W. R., F. T. Lindgren, and E. L. Bierman. 1970. Very low density lipoprotein subfractions in a subject with broad- $\beta$ disease (type III hyperlipoproteinemia) and a subject with endogenous lipemia (type IV). Chemical composition and electrophoretic mobility. Biochim. Biophys. Acta. 202:517-525.

25. Quarfordt, S., R. I. Levy, and D. S. Fredrickson. 1971. On the 
lipoprotein abnormality in type III hyperlipoproteinemia. J. Clin. Invest. $50: 754-751$.

26. Hazzard, W. R., and E. L. Bierman. 1975. The spectrum of electrophoretic mobility of very low density lipoproteins: role of slower migrating species in endogenous hypertriglyceridemia (type IV hyperlipoproteinemia) and broad- $\beta$ disease (type III). J. Lab. Clin. Med. 86:239-252.

27. Chappell, D. A. 1988 . Pre- $\beta$-very low density lipoproteins as precursors of $\beta$-very low density lipoproteins: a model for the pathogenesis of familial dysbetalipoproteinemia (type III hyperlipoproteinemia). J. Clin. Invest. 82:628-639.

28. Quarfordt, S. H., R. I. Levy, and D. S. Fredrickson. 1973. The kinetic properties of very low density lipoprotein triglyceride in type III hyperlipoproteinemia. Biochim. Biophys. Acta. 296:572-576.

29. Shore, V. G., B. Shore, and R. G. Hart. 1974. Changes in apolipoproteins and properties of rabbit very low density lipoproteins on induction of cholesterolemia. Biochemistry. 13:1579-1584.

30. Daugherty, A., K. Oida, B. E. Sobel, and G. Schonfeld. 1988. Dependence of metabolism and structural heterogeneity of cholesterol ester-rich very low density lipoproteins on the duration of cholesterol feeding in rabbits. J. Clin. Invest. 82:562-570.

31. Mahley, R. W., T. L. Innerarity, K. H. Weisgraber, and D. L. Fry. 1977. Canine hyperlipoproteinemia and atherosclerosis. Am. J. Pathol. 87:205-226.

32. Stalenhoef, A. F. H., M. J. Malloy, J. P. Kane, and R. J. Havel. 1986. Metabolism of apolipoproteins B-48 and B-100 of triglyceriderich lipoproteins in patients with familial dysbetalipoproteinemia. $J$. Clin. Invest. 78:722-728.

33. Edelstein, C., and A. M. Scanu. 1986. Precautionary measures for collecting blood destined for lipoprotein isolation. Methods Enzymol. 128:151-155.

34. Havel, R. J., H. A. Eders, and J. H. Bragdon. 1955. The distribution and chemical composition of ultracentrifugally separated lipoproteins in human serum. J. Clin. Invest. 34:1345-1353.

35. Lossow, W. J., F. T. Lindgren, J. C. Murchio, G. R. Stevens, and L. C. Jensen. 1969. Particle size and protein content of six fractions of the $S_{\mathrm{f}}>20$ plasma lipoproteins isolated by density gradient centrifugation. J. Lipid Res. 10:68-76.

36. Kunkel, H. G., and R. Trautman. 1956. The $\alpha_{2}$ lipoproteins of human serum. Correlation of ultracentrifugal and electrophoretic properties. J. Clin. Invest. 35:641-648.

37. Mahley, R. W., and K. H. Weisgraber. 1974. Canine lipoproteins and atherosclerosis. I. Isolation and characterization of plasma lipoproteins from control dogs. Circ. Res. 35:713-721.

38. Lowry, O. H., N. J. Rosebrough, A. L. Farr, and R. J. Randall. 1951. Protein measurement with the Folin phenol reagent. J. Biol. Chem. 193:265-275.

39. Bartlett, G. R. 1959. Phosphorus assay in column chromatography. J. Biol. Chem. 234:466-468.

40. Laemmli, U. K. 1970. Cleavage of structural proteins during the assembly of the head of bacteriophage T4. Nature (Lond.). 227:680-685.

41. Morrissey, J. H. 1981. Silver stain of proteins in polyacrylamide gels: a modified procedure with enhanced uniform sensitivity. Anal. Biochem. 117:307-310.

42. Weisgraber, K. H., and R. W. Mahley. 1978. Apoprotein (EAII) complex of human plasma lipoproteins. J. Biol. Chem. 253:6281-6288.

43. Forte, T. M., and R. W. Nordmausen. 1986. Electron microscopy of negatively stained lipoproteins. Methods Enzymol. 128:442457.

44. Sata, T., R. J. Havel, and A. L. Jones. 1972. Characterization of subfractions of triglyceride-rich lipoproteins separated by gel chromatography from blood plasma of normolipemic and hyperlipemic humans. J. Lipid Res. 13:757-768.

45. Innerarity, T. L., R. E. Pitas, and R. W. Mahley. 1980. Receptor binding of cholesterol-induced high-density lipoproteins containing predominantly apoprotein $E$ to cultured fibroblasts with mutations at the low-density lipoprotein receptor locus. Biochemistry 19:43594365 .

46. Bilheimer, D. W., S. Eisenberg, and R. I. Levy. 1972. The metabolism of very low density lipoprotein proteins. I. Preliminary in vitro and in vivo observation. Biochim. Biophys. Acta. 260:212-221.

47. De Lean, A., P. J. Munson, and D. Rodbard. 1978. Simultaneous analysis of families of sigmoidal curves: application to bioassay, radioligand assay, and physiological dose-response curves. Am. J. Physiol. 235:E97-E102.

48. De Lean, A., A. A. Hancock, and R. J. Lefkowitz. 1982. Validation and statistical analysis of a computer modeling method for quantitative analysis of radioligand binding data for mixtures of pharmacological receptor subtypes. Mol. Pharmacol. 21:5-16.

49. Weisgraber, K. H., T. L. Innerarity, K. J. Harder, R. W. Mahley, R. W. Milne, Y. L. Marcel, and J. T. Sparrow. 1983. The receptor-binding domain of human apolipoprotein E: monoclonal antibody inhibition of binding. J. Biol. Chem. 258:12348-12354.

50. Milne, R. W., R. Theolis, Jr., R. B. Verdery, and Y. L. Marcel. 1983. Characterization of monoclonal antibodies against human low density lipoproteins. Arteriosclerosis. 3:23-30.

51. Young, S. G., J. L. Witztum, D. C. Casal, L. K. Curtiss, and S. Bernstein. 1986. Conservation of the low density lipoprotein receptorbinding domain of apolipoprotein B: demonstration of a new monoclonal antibody, MB47. Arteriosclerosis. 6:178-188.

52. Hui, D. Y., T. L. Innerarity, and R. W. Mahley. 1984. Defective hepatic lipoprotein receptor binding of $\beta$-very low density lipoproteins from type III hyperlipoproteinemic patients. Importance of apolipoprotein E. J. Biol. Chem. 259:860-869.

53. Milne, R. W., P. K. Weech, L. Blanchette, J. Davignon, P. Alaupovic, and Y. L. Marcel. 1984. Isolation and characterization of apolipoprotein B-48 and B-100 very low density lipoproteins from type III hyperlipoproteinemic subjects. J. Clin. Invest. 73:816-823.

54. Fainaru, M., R. W. Mahley, R. L. Hamilton, and T. L. Innerarity. 1982. Structural and metabolic heterogeneity of $\beta$-very low density lipoproteins from cholesterol-fed dogs and from humans with type III hyperlipoproteinemia. J. Lipid Res. 23:702-714.

55. Kane, J. P., G. C. Chen, R. L. Hamilton, D. A. Hardman, M. J. Malloy, and R. J. Havel. 1983. Remnants of lipoproteins of intestinal and hepatic origin in familial dysbetalipoproteinemia. Arteriosclerosis. 3:47-56.

56. Innerarity, T. L., K. S. Arnold, K. H. Weisgraber, and R. W. Mahley. 1986. Apolipoprotein $\mathrm{E}$ is the determinant that mediates the receptor uptake of $\beta$-very low density lipoproteins by mouse macrophages. Arteriosclerosis. 6:114-122.

57. Mahley, R. W., T. L. Innerarity, R. E. Pitas, K. H. Weisgraber, J. H. Brown, and E. Gross. 1977. Inhibition of lipoprotein binding to cell surface receptors of fibroblasts following selective modifications of arginyl residues in arginine-rich and B apoproteins. J. Biol. Chem. 252:7279-7287.

58. Weisgraber, K. H., T. L. Innerarity, and R. W. Mahley. 1978. Role of the lysine residues of plasma lipoproteins in high affinity binding to cell surface receptors on human fibroblasts. J. Biol. Chem. 253:9053-9062.

59. Mahley, R. W., T. L. Innerarity, K. H. Weisgraber, and S. Y. Oh. 1979. Altered metabolism (in vivo and in vitro) of plasma lipoproteins after selective chemical modification of lysine residues of the apoproteins. J. Clin. Invest. 64:743-750.

60. Bilheimer, D. W., Y. Watanabe, and T. Kita. 1982. Impaired receptor-mediated catabolism of low density lipoprotein in the WHHL rabbit, an animal model of familial hypercholesterolemia. Proc. Natl. Acad. Sci. USA. 79:3305-3309.

61. Breckenridge, W. C., J. A. Little, P. Alaupovic, C. S. Wang, A. Kuksis, G. Kakis, F. Lindgren, and G. Gardiner. 1982. Lipoprotein abnormalities associated with a familial deficiency of hepatic lipase. Atherosclerosis. 45:161-179.

62. Mann, A. W., R. E. Gregg, R. Ronan, F. Thomas, L. A. Zech, and H. B. Brewer, Jr. 1988. Apolipoprotein E-I $\mathrm{I}_{\text {Harrishurg }}$ : a point muta tion resulting in dominant expression of type III hyperlipoproteinemia. Circulation. 78:1558. (Abstr.) 